\title{
STUDIES ON PARAMPHISTOMIASIS IN RUMINANTS
}

\author{
Magdy H. Al-Gaabary, Salama A. Osman and Amera G.M. El-Tonoby \\ Department Of Animal Medicine, Faculty Of Veterinary Medicine, \\ Kafrelsheikh University, Kafr El-Sheikh 33516, Egypt
}

\begin{abstract}
This study was carried out through one year from January 2008 to December 2008 at Kafr El-Sheikh Governorate to determine some epidemiological and clinical features concerning paramphistomiasis in ruminants. Moreover, different treatment trails were conducted to evaluate their efficacy. Out of 944 examined animals (316 cattle 218 buffalos and 410 sheep), eggs of paramphistomes were detected in $260(27.43 \%)$, the prevalence rate was $38.92 \%, 41.74 \%$ and $10.98 \%$ among cattle, buffaloes and sheep respectively. Geographically, the disease was distributed variably among different areas of Kafr ElSheikh. Concerning the sex predisposition, the prevalence of the disease was significantly higher $(p<0.05)$ in females $(41.61 \%)$ than males $(27.45 \%)$. The prevalence of paramphistomiasis was differed significantly among different age groups and different seasons. Clinically, mild infected animals were apparently normal; the moderate and severely infected animals developed diarrhea, emaciation, submandibular edema, rough coat and decreased milk yield in variable degrees correlated to the faecal egg count. Paramphistomes species which detected were Paramphistomum cervi, Carmyerius gregarious, and Cotylophoron cotylophorum. Histopathological changes in infected animals were in the form of mononuclear cell infiltration in the sub mucosa of the ruminal papillae, necrosis and degeneration in the gland of the duodenum. It was observed that oxyclozamide was 97.9\% effective against mature paramphistomes whereas niclosamide failed to cure completely any of the infected animals.
\end{abstract}




\section{INTRODUCTION}

Helminthiasis is one of the most important groups of parasitic diseases in several countries. Among these infections, paramphistomes are the most common and pathogenic (Manna et al., 1994).

Paramphistomiasis is caused by digenetic flukes belong to the family Paramphistomidae. Adult paramphistomes are the main parasites in the rumen and reticulum of sheep, goats, cattle and water buffaloes. Light infection dose not cause serious damage to the animals, but massive number of immature paramphistomes can migrate through the intestinal tract causing acute parasitic gastroenteritis with high morbidity and mortality rates, particularly in young animals (Hanna et al., 1988). Mature Paramphistomes are also responsible for ruminitis, irregular rumination, unthriftiness, loss of body condition, decrease in milk production and reduction of fertility (Zinsstag et al., 1997).

Paramphistomiasis is distributed all over the world, but its highest prevalence has been reported in tropical and subtropical regions, particularly in Africa, Asia, Australia, Eastern Europe and Russia (Sey et al., 1997).

Diagnosis of paramphistomiasis is mainly based on faecal examination (Hanna et al., 1988). While early diagnosis of such trematode is so difficult where, the egg output is not present in faeces until the fluke reach the maturity (Hafeez et al., 2006).

To control paramphistomes infection in livestock a variety of anthelmintics as resorantel and rafoxanide (Soulsby, 1982), thiophonate and albendazole (Mahapatra et al., 1990) triclobendazole (Galdhar et al., 2002), niclozamide (Reddy and Hafeez, 1986) have been used with varying results. But the literature on the efficacy of oxyclozanide against paramphistomiasis is meager except a few (Prasad and Bharti 2001). 
Economic losses caused by Paramphistomes infection has not been estimated, but may be greater than those caused by many other parasites (Hanna et al., 1988).

So, the aim of the present work was directed to study some epidemiological features and clinico-pathological aspects associated with Paramphistomiasis in cattle, buffaloes and sheep in addition to evaluate some trials for treatment of naturally infected animals.

\section{MATERIALS AND METHODS}

\section{Animals:}

A total of 944 animals (316 cattle, 218 buffaloes and 410 sheep) of different ages and sex belong to Kafr El-Sheikh Governorate were used in this study. These animals were subjected to clinical, epidemiological and parasitological investigation against paramphistomiasis during the period from January, 2008 to December 2008.

\section{Faecal samples:}

Individual faecal sample was collected directly from the rectum of each animal. Each sample was labeled and transported as soon as possible to the Laboratory of Infectious Diseases, Faculty Veterinary Medicine, Kafrelsheikh University for macroscopic and microscopic examination.

\section{Samples for histopathological examinations:}

At Kafr El-Sheikh abattoir, Rumens, reticulums and duodenums showed gross lesions from paramphistomes infected animals were collected and fixed in $10 \%$ neutral buffered formalin solution. 


\section{Collection of the flukes:}

Rumens and reticulums of 220 animals (172 buffaloes, 43 cattle, 5 sheep) freshly slaughtered in Kafrelsheikh abattoir were examined for the presence of the ruminal flukes. The collected flukes were transported to the laboratory in plastic container provided with physiological saline. The collected flukes were washed several times in tap water to remove the debris and ruminal content according to Asanji (1990) then prepared for identification. The flukes were examined under microscope for identification according the key of Yamaguti (1958).

\section{Epidemiological investigation:}

Prevalence rate, age and sex susceptibility relationships as well as the seasonality of paramphistomiasis were estimated according to Martin (1987).

\section{Clinical examination:}

All animals under study were subjected to clinical examination according to Kelly (1984).

\section{Parasitological examination:}

Faecal examination, total egg counts and identification of the recovered flukes were carried out according to Yamaguti (1958) and Soulsby (1982).

\section{Histopathological examination:}

The specimens for histopathological examination were embedded in paraffin wax. Five microns thick paraffin section were prepared and stained with haematoxylene and Eosin $(\mathrm{H} \& \mathrm{E})$ then examined microscopically according to Drurag and Wallington (1980). 


\section{Treatment trails:}

Seventy three animals (22 cattle, 23 buffaloes and 28 sheep) of 2-6 years naturally infected with paramphistomes were used for treatment trials. Mixed infection with other parasites was excluded. These animals were divided into two groups. The first group consisted of 48 animals (15 sheep, 17 cows and 16 buffaloes) which treated using oxyclozanide (zanil) (Shering plough veterinaire) at a dose rate of $10 \mathrm{mg} / \mathrm{kg}$ body weight. The second group consisted of 25 animals (13 sheep, 4 buffaloes and 8 cattle) which treated using niclosamide (Adwia) at dose $100 \mathrm{mg} / \mathrm{kg}$ body weight. Faecal egg counts were estimated on day zero treatment and then at 7, 14, 21 and 28 days post treatment. The efficacy of the drug was evaluated on the basis of faecal egg count.

\section{Statistical analysis:}

The obtained data had been analyzed statistically using chi-square and student t-test according to Snedecor and Cochran (1980).

\section{RESULTS AND DISCUSSION}

Paramphistomiasis has been a neglected trematode infectious disease; recently, it emerged as an important cause of productivity loss (Anuracpreeda et al., 2008).

Total prevalence which recorded in this study was $27.43 \%$. Table (1) revealed that the prevalence was significantly higher $(P<0.001)$ in cattle and buffaloes than that of sheep, whereas the variation was not significant between cattle and buffaloes. This variation of the disease prevalence among different species may be attributed to the host specificity in addition to the rate of exposure where, cattle and buffaloes were exposed similarly compared to a little exposure of sheep. Lower 
rates were recorded by Agosti et al. (1980) who recorded 16.9\% cumulative incidence and Kozakiewicz (1980) who recorded 3.06\% prevalence from 1971-1973 and 17.29\% from 1976-1978.

Regarding to the prevalence rate in cattle, it was $38.92 \%$. Similar rates were recorded by Bouvry and Rau (1984) who recorded 34\% prevalence rate. Lower prevalence was recorded by Vartic et al. (1982) who recorded $3 \%$ prevalence rate; Juyal et al. (2003) who recorded $4.46 \%$ prevalence rate; Dube et al. (2004) who recorded $25.41 \%$ prevalence rate and Haridy et al. (2006) who recorded $7.3 \%$ prevalence rate of paramphistomiasis. Higher rates were recorded by Manna et al. (1994); Dube et al. (2004) and Stripalwit et al. (2007) who recorded 56.5\%, 80\% and $78.38 \%$ prevalence rates respectively.

Regarding to the prevalence of the disease among examined buffaloes, the prevalence was $41.74 \%$. Higher rates were recorded by Luc and Thang (1999) and Ameni et al. (2001) who recorded $72.7 \%$ and $75 \%$ prevalence rates respectively. Lower rates were recorded by $\boldsymbol{E l - R e f a i i}$ (1993); Manna et al. (1994); Juyal et al. (2003); Haridy et al. (2006) and Khan et al. (2006) who recorded 9\%, 27.4\%, 6.59\%, 10\% and $28.33 \%$ prevalence rate respectively.

The prevalence of the disease among sheep was $10.98 \%$. Similar rate was recorded by Vartic et al. (1982) who recorded 9-11\% prevalence rate. Higher prevalence were recorded by Manna et al. (1994) and Wang et al. (2006) who recorded $55.9 \%$ and $48.8 \%$ prevalence rates respectively. Lower rates were recorded by Moghoddar and Khanitapeh (2003) and Haridy et al. (2006) who recorded $1.09 \%$ and $4 \%$ prevalence rates respectively. 
As shown in Table (2), the prevalence of the disease was differed among different areas of Kafr El-Sheikh Governorate where higher prevalence was recorded in El-Riade (61.76\%) and Biala (53.65\%) compared to zero\% in Baltim, this variation among different area might be related to the environmental conditions which facilate the presence and propagation of the intermediate host (Al-Gaabary and Nasr, 1997). Climatic changes (Rangel-Ruiz et al., 2003) and husbandry practices (Wang et al., 2006).

Concerning the sex predispoition of paramphistomiasis, significant $(P \leq 0.05)$ increase was recorded in female $(41.61 \%)$ than males $(27.45 \%)$ in livestock (Table 3 ). Similar observations were reported previously by Asanji et al. (1989) and Galdhar and Roy (2005) who recorded that the prevalence of paramphistomiasis was generally higher in females than males. On the contrary, Sevimi et al. (2005); kumari and Hafeez (2005) and Khan et al. (2006) recorded that the prevalence of paramphistomiasis in males was higher than that in females. The higher prevalence in females may be attributed to stress factors (parturition and lactation) to which the females were exposed.

Concerning the disease prevalence among examined cattle and buffaloes in relation to their ages, the prevalence of paramphistomiasis was zero \% in cattle less than one year, $51.6 \%$ in cattle from $1-2$ year, $44.55 \%$ in cattle from 2-4 year and $53.48 \%$ in cattle more than 4 year. Whereas the prevalence rates in buffaloes were $6.25 \%$ in age group less than 1 year, $45.71 \%$ in age group 12 year, $53.33 \%$ in age group 2-4 years and 55\% in buffaloes more than 4 years (Table 4). Similar result were previously reported by Agosti et al. (1980) who recorded that all cases of paramphistomiasis were observed in adult cattle whereas no cases were reported in calves; Ferre et al. (1997) who 
recorded that the risk of paramphistomiasis infestation was increased with increasing the animal age; Amer et al. (2002) who recorded that the incidence of paramphistomiasis in cattle over $2 \frac{1}{2}$ years was $46.77 \%$ while it was $28.9 \%$ in cattle under $2 \frac{1}{2}$ year and Galdhar and Roy (2005) who recorded $1.25 \%$ prevalence in animal above 6 years followed by calves of one year (4.34\%). On the other hand, Sobih and Hassan (1992) recorded $2.9 \%$ and zero $\%$ prevalence rates in cattle and buffaloes in yearling animals and $1.7 \%$ and zero \% in animal over 3 year and Khan et al. (2006) who recorded that the disease was prevalent in younger buffaloes below two year compared to older buffaloes more than two year. The lower rate of infection in young animals may be attributed to the little chance of exposure as well as the long prepatent period of the paramphistomes species with subsequent absence of the diagnostic eggs.

Concerning the disease prevalence in relation to different seasons, the prevalence was statistically $(P \leq 0.05)$ differ among different seasons. The disease was higher in spring $(50.81 \%)$, followed by autumn $(36.03 \%)$ then winter $(34.48 \%)$ and lastly summer (34.12\%) (Table 5). Similar findings were previously recorded by Pal and Qayyum (1993) who recorded highest paramphistomes infection rate during winter ( $84.18 \%)$ followed by autumn $(41.76 \%)$ then spring $(37.25 \%)$ and finally in summer (32.86\%) and Wang et al. (2006) who recorded that summer showed the peak season for paramphistomes infection in sheep. This variation among different studies might be related to environmental conditions which facilitate the presence of the intermediate host (AlGaabary and Nasr, 1997) climatic and geographical parameters which affect the hatchability of paramphistomes eggs (Dutta et al., 1995 and Hirani et al., 1999). 
The clinical findings which recorded in this study were greatly related to the degree of infestation; mildly infected ones showed no clinical signs while moderately and severely infected animals showed emaciation, diarrhoea, pale mucous membrane, submandibular oedema and decreased milk yield. These signs may be attributed to the damage and necrosis of gastro intestinal mucosa which results from direct effect of the parasite which lead to impairment of digestion and absorption resulting in production loss. Submanidublar oedema which observed may be attributed to hypoproteinemia which resulted due to leakage of protein through the damaged mucous membrane of the duodenum. Decreased milk yield is due to decrease of volatile fatty acids (Amer et al., 2002). Similar signs were observed previously by Hanna et al. (1988) who recorded that light paramphistomiasis infection did not cause serious damage to the animal and Amer et al. (2002) who recorded that pale mucous membrane, weakness, weight loss, decreased milk yield in paramphistomes infected animals.

Paramphistomes species that identified in this study were Paramphistomum cervi, Carmyerius gregarious and Cotylophoron cotylophorum (Figures $1 \mathrm{a}, \mathrm{b}$ and c). Paramphistomum cervi and Cotylophoron cotylophorum were recovered from cattle, buffaloes and sheep, while, Carmyerius gregarious was recovered only from buffaloes. Nearly similar finding was reported previously by El-Seify et al. (1999) who detected Carmyerius gregarious and Cotylophoron cotylophorum in slaughtered cattle and buffaloes at Kafr EL-Sheikh abattoir.

The pathological findings that associated with paramphistomiasis were occurred as a result of suckling the reticulum and rumen mucosa by their acetabulum (Figures $1 \mathrm{~d}$ ). leading to slightly hardened areas devoid of ruminal papillae in addition to atrophy of ruminal papillae, necrosis and erosion of ruminal mucous membrane (Figures 1 e and f). Similar observations were recorded by Vartic et al. (1982), Khan et al. (1994) and Dube et al.(2004). 
Histopathological changes of paramphistomiasis infected animals were in the form of mononuclear cell infiltration in submucosa of ruminal papillae. The lesions of the duodenum were in the form of necrosis and degeneration of glands replaced with infiltration of inflammatory cells due to invasion of immature paramphistomes species inside the duodenum tissue (Figures 2 a, b, c and d). Similar histopathological findings were reported by Singh et al. (1984) who recorded macrophages and lymphocyte infiltrations in the duodenum tissue and mononuclear infiltration in the ruminal mucosa and Rolfe et al. (1994) who recorded eosinophils, mast cells and leukocytic infiltration.

Chemicals still the main available tool for controlling different parasitic diseases (Campbell and Benz, 1984). A variety of anthelmintics e.g resorantel and rafoxanide (Soulsby, 1982), thiophanate and albendazole (Mahapatra et al., 1990), triclabendazole (Galdhar et al., 2002) were used for control of paramphistomiasis with variable results.

In this study, the efficacy of oxyclozanide and niclosamide were evaluated in treatment of paramphistomiasis in naturally infected animals. It was observed that oxyclozanide was $97.9 \%$ effective whereas niclosamide fail to cure completely any of the infected animals (Table 6). However, niclosamide was diminished the faecal egg count in previous studies, oxyclozanide gave $72.61 \%$ efficacy (Rapic, 1980); $99.9 \%$ to $100 \%$ efficacy against adult paramphistomes and $98.1 \%$ efficacy against immature paramphistomes (Rolfe and Boray, 1987); 100\% efficacy against paramphistomes (El-Seify et al., 1999) and 90.6\% efficacy (Roy et al., 2004).

Finally, it can be concluded that, Paramphistomiasis is an endemic disease affecting ruminants at Kafr El-Sheikh. The prevalence rate was varied with species, age, sex, season and locality. The clinical reaction of the disease is greatly correlated to the faecal egg count. The adult flukes result in significance changes in blood picture of the affected animals. The adult flukes result in macroscopic and microscopica histopathological 
changes which reflect and determine the clinical picture of the disease. The recovered spp. Of paramphistomes were Paramphistomum cervi, Carmyerius gregarious, and Cotylophoron cotylophorum. Oxyclozanide provide high efficiency $97.9 \%$ in treatment of paramphistomasis.

\section{Acknowledgement:}

Authors would like to express their appreciation to Dr. Mahmoud El-Seify Professor and head of parasitology department and Dr. Mohamed S. Ahmed lecturer of Pathology, Fac. of Vet. Med. Kafrelsheikh University for their help during conducting parasitological and histopathological aspects of this work.

Table (1): Prevalence of paramphistomiasis in livestock.

\begin{tabular}{||c||c||c||c|}
\hline Animal species & Number of examined animals & Number of infected animals & Morbidity rate \\
\hline \hline Cattle & 316 & 123 & $38.92 \%^{\mathrm{a}}$ \\
Buffaloes & 218 & 92 & $41.74 \%^{\mathrm{a}}$ \\
Sheep & 410 & 45 & $10.98 \%^{\mathrm{b}}$ \\
\hline \hline Total & 944 & 260 & $27.43 \%$ \\
\hline
\end{tabular}

Numbers within the same column with different superscripts are significantly different from each others at $P<0.05$.

Table (2): Distribution of paramphistomiasis among different areas at Kafr ElSheikh Governorate.

\begin{tabular}{||l||c|c|c||}
\hline \multicolumn{1}{|c||}{ Area } & \multicolumn{3}{c||}{ Total examined animal } \\
\cline { 2 - 4 } & No. examined animal & No. infected animal & Morbidity Rate \\
\hline \hline Kafr El-Sheikh & 501 & 103 & $20.55 \%$ \\
Desouk & 62 & 19 & $30.64 \%$ \\
El-Riade & 34 & 21 & $61.76 \%$ \\
Kalleen & 29 & 12 & $41.37 \%$ \\
Billa & 41 & 22 & $53.65 \%$ \\
Fowa & 20 & 7 & $35 \%$ \\
Mitobos & 55 & 22 & $40 \%$ \\
El-Hamoul & 51 & 9 & $17.64 \%$ \\
Balteem & 25 & 45 & Zero $\%$ \\
Sidi-Salem & 126 & $45.71 \%$ \\
\hline \hline
\end{tabular}

Kafrelsheikh Vet. Med. J. Vol. 7 No. 1 (2009) 
Magdy H. Al-Gaabary et al.,

Table (3): Prevalence of paramphistomiasis among cattle and buffaloes in relation to sex in livestock.

\begin{tabular}{|c||c||c|c|}
\hline Sex & No. of examined animals & No of infected animals & Morbidity rate \\
\hline \hline Male & 51 & 14 & $27.45 \%$ \\
\hline Female & 483 & 201 & $41.61 \% *$ \\
\hline
\end{tabular}

* Significant at $P<0.05$

Table (4): Prevalence of paramphistomiasis among cattle and buffaloes in relation to animal age.

\begin{tabular}{|c|c|c|c|c|c|c|c|c|c|}
\hline \multirow{2}{*}{ Age } & \multicolumn{3}{|c|}{ Cattle } & \multicolumn{3}{|c|}{ Buffaloes } & \multicolumn{3}{|c|}{ Total } \\
\hline & $\begin{array}{c}\text { Examined } \\
\text { animal }\end{array}$ & $\begin{array}{c}\text { Infected } \\
\text { animal }\end{array}$ & $\begin{array}{c}\text { Morbidity } \\
\text { rate }\end{array}$ & $\begin{array}{c}\text { Examined } \\
\text { animal }\end{array}$ & $\begin{array}{c}\text { Infected } \\
\text { animal }\end{array}$ & $\begin{array}{l}\text { Morbidity } \\
\text { rate }\end{array}$ & $\begin{array}{c}\text { Examined } \\
\text { animal }\end{array}$ & $\begin{array}{c}\text { Infected } \\
\text { animal }\end{array}$ & $\begin{array}{c}\text { Morbidity } \\
\text { rate }\end{array}$ \\
\hline$<1$ year & 67 & Zero & Zero\% & 48 & 3 & $6.25 \%$ & 115 & 3 & $2.60 \%$ \\
\hline 1-2 year & 62 & 32 & $51.6 \%$ & 35 & 16 & $45.71 \%$ & 97 & 48 & $49.48 \%$ \\
\hline 2-4 year & 101 & 45 & $44.55 \%$ & 75 & 40 & $53.33 \%$ & 176 & 85 & $48.29 \%$ \\
\hline$>4$ year & 86 & 46 & $53.48 \%$ & 60 & 33 & $55 \%$ & 146 & 79 & $54.10 \%$ \\
\hline
\end{tabular}

Table (5): Prevalence of paramphistomiasis among cattle and buffaloes in relation to seasonal variation.

\begin{tabular}{|c|c|c|c|c|c|c|c|c|c|}
\hline \multirow{2}{*}{ Age } & \multicolumn{3}{|c|}{ Cattle } & \multicolumn{3}{|c|}{ Buffaloes } & \multicolumn{3}{|c|}{ Total } \\
\hline & $\begin{array}{c}\text { Examined } \\
\text { animal }\end{array}$ & $\begin{array}{c}\text { Infected } \\
\text { animal }\end{array}$ & $\begin{array}{c}\text { Morbidity } \\
\text { rate }\end{array}$ & $\begin{array}{c}\text { Examined } \\
\text { animal }\end{array}$ & $\begin{array}{c}\text { Infected } \\
\text { animal }\end{array}$ & $\begin{array}{c}\text { Morbidity } \\
\text { rate }\end{array}$ & $\begin{array}{c}\text { Examined } \\
\text { animal }\end{array}$ & $\begin{array}{c}\text { Infected } \\
\text { animal }\end{array}$ & $\begin{array}{c}\text { Morbidity } \\
\text { rate }\end{array}$ \\
\hline Winter & 21 & 4 & $19 \%$ & 8 & 6 & $75 \% *$ & 29 & 10 & $34.48 \%$ \\
\hline Spring & 103 & 48 & $46.6 \%$ & 80 & 45 & $56.25 \%$ & 183 & 93 & $50.81 \%$ \\
\hline Summer & 102 & 44 & $43.13 \%$ & 109 & 28 & $25.68 \%$ & 211 & 72 & $34.12 \%$ \\
\hline Autumn & 90 & 27 & $30 \%$ & 21 & 13 & $61.90 \%$ & 111 & 40 & $36.03 \%$ \\
\hline
\end{tabular}

* Significant of $P \leq 0.05$

Table (6): Efficacy of oxyclozanide and niclosamide in infected animals.

\begin{tabular}{|c|c|c|c|c|c|c|c|c|}
\hline \multirow{3}{*}{$\begin{array}{c}\text { Treated group } \\
\text { Niclosamide } N=25\end{array}$} & \multicolumn{8}{|c|}{ Parasitological cure } \\
\hline & \multicolumn{2}{|c|}{$1^{\text {st }}$ week } & \multicolumn{2}{|c|}{$2^{\text {nd }}$ week } & \multicolumn{2}{|c|}{$3^{\text {rd }}$ week } & \multicolumn{2}{|c|}{$4^{\text {th }}$ week } \\
\hline & 0 & $0 \%$ & 0 & $0 \%$ & 0 & $0 \%$ & 0 & $0 \%$ \\
\hline Oxyclozanide $\mathrm{N}=48$ & 47 & $97.9 \%$ & 47 & $97.9 \%$ & 47 & $97.9 \%$ & 47 & $97.9 \%$ \\
\hline
\end{tabular}

Kafrelsheikh Vet. Med. J. Vol. 7 No. 1 (2009) 

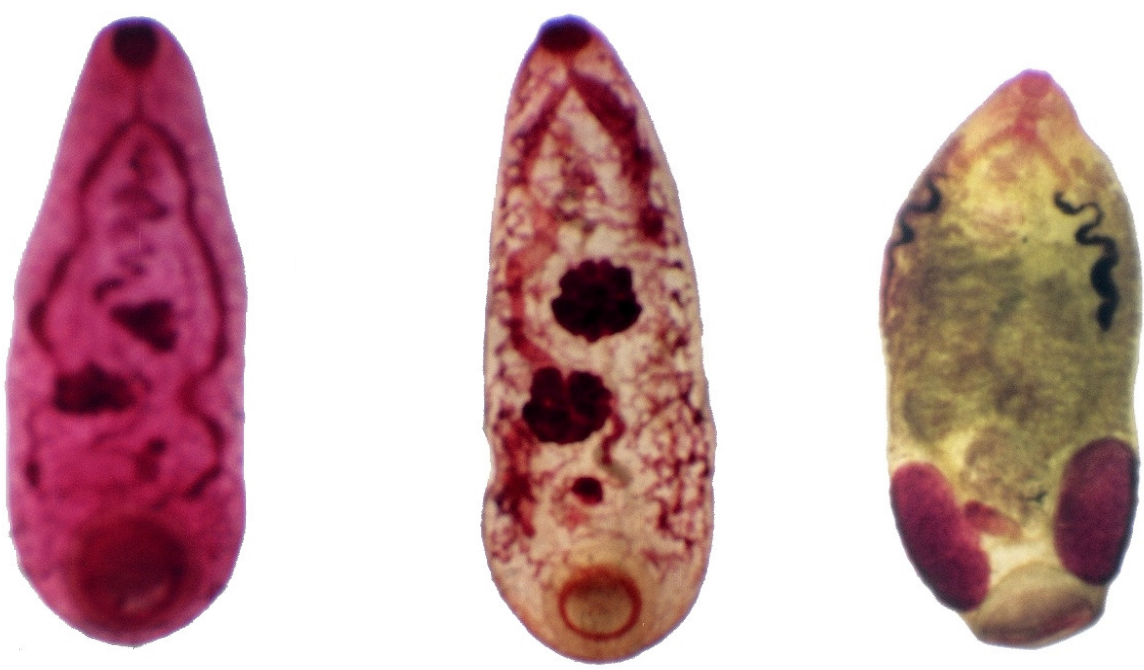

(A)

(B)

(C)

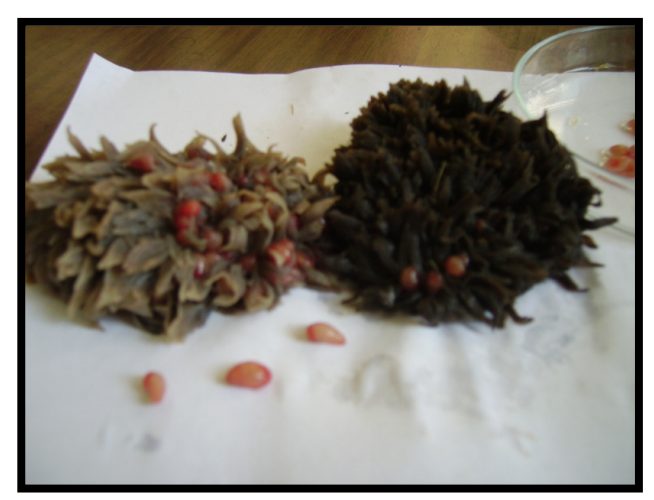

(D)

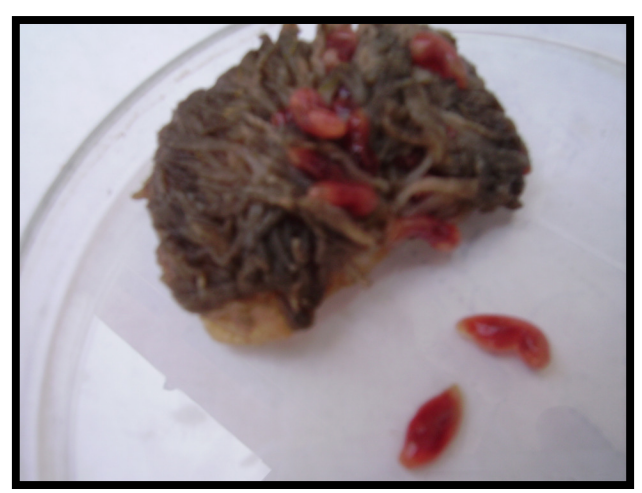

(E)

Fig. (1):
(a) Carmyerius gregarious.
(b) Cotylophoron cotylophorum
(c) Paramphistomum cervi
(d) Attachment of paramphistomum spp. with rumen mucosa
(e) Different degrees of rumen infestations with paramphistomum spp
(f) Rumen heavily infected with Carmyerius gregarious

Kafrelsheikh Vet. Med. J. Vol. 7 No. 1 (2009) 
Magdy H. Al-Gaabary et al.,

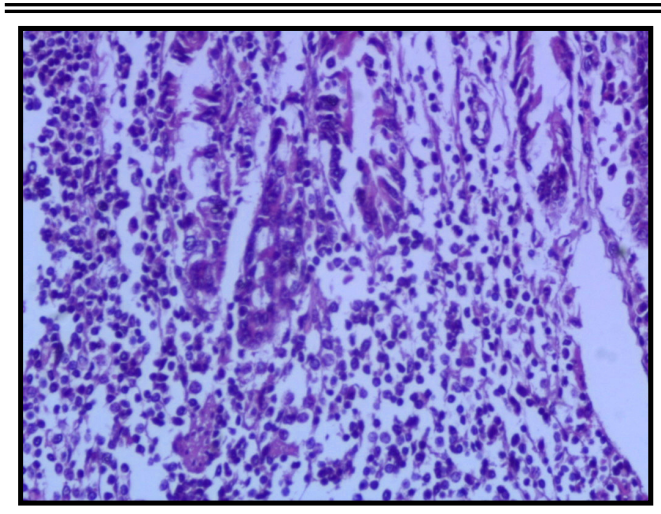

(A)

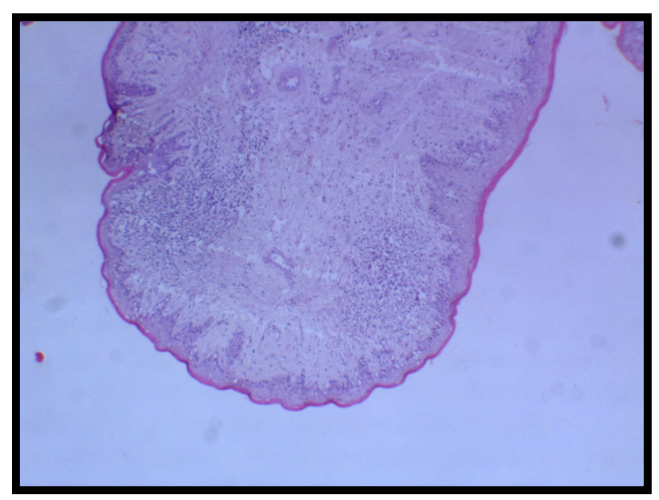

(C)

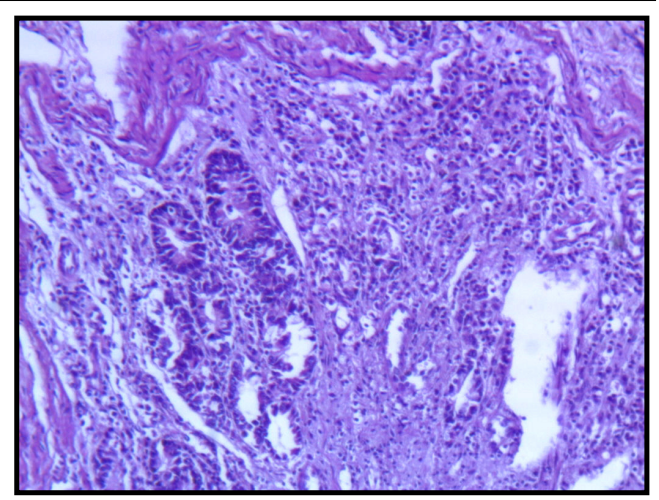

(B)

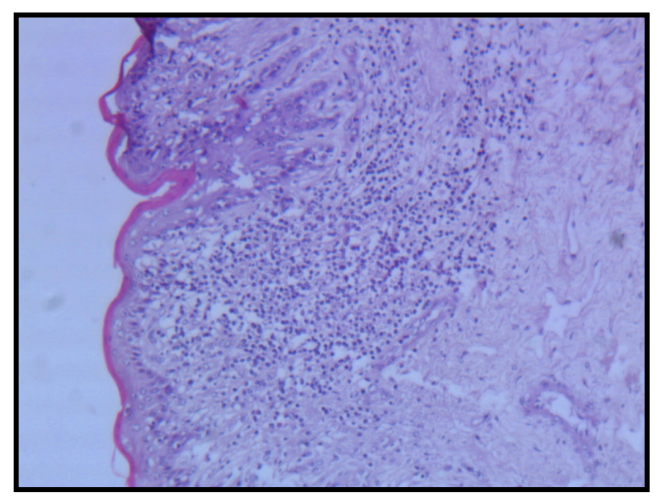

(D)

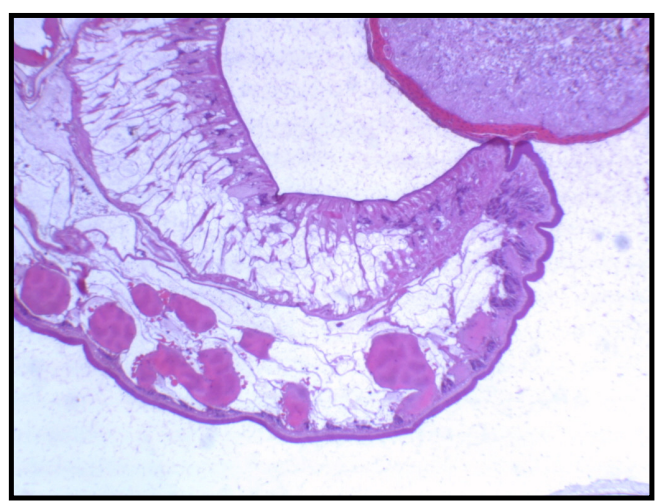

(E)

Fig. (2): - Degenerative changes in the duodenal glands with inflammatory cell infiltration (a) X 100 and (b) X200

- Rumen papillae showing mononuclear cell infiltration in the sub mucosa (c) X 200 and (d) X 400. 


\section{REFERENCES}

- Agosti, M.; Cavalletii, E. and Pozza, O. (1980). Bovine paramphistomiasis in the province of Milan. Clinical and epizootiological investigations. Clinica-Veterinaria, 103(5): 284-296.

- Al-Gaabary, M.H. and Nasr, M.Y. (1997). Epidemiological, clincobiochemical and electrophoretic studies on paramphistomiasis in buffaloes in Kafr El-Sheikh province. Zagazig Veterinary Journal, 25(3): 34-40.

- Ameni, G.; Erko, B. and Bogale, T. (2001). Preliminary study on the major bovine trematode infection around Kemissie, North eastern Ethiopia and treatment trial with Praziquantel. Bulletin of Animal Health and Production in Africa, 49(2): 62-67.

- Amer, A.; Osman, S.A. and Harfoush, M.A. (2002). Epizootiological and serological studies on Fascioliasis and Paramphistomiasis in cattle. Zagazig Veterinary Journal, 30(1): 107-116.

- Anuracpreeda, P.; Wanichanon, C. and Sobhon, P. (2008). Paramphistomum cervi: Antigenic profile of adults as recognized by infected cattle sera. Experimental Parasitology, 118: 203-207.

- Asanji,M.F.(1989).Paramphistomiasis of cattle in sierra leone.Cameroon and seasonal fluctuation in its prevalence. Bulletin of Animal Health and Production in Africa, 37(4): 327-331.

- Asanji,M.F.(1990). Experimental determination of Snail intermediate host of live stock paramphistomes and their distribution in snails in nature. Bull. Anim. Health. Prod. Afr. 38: 151-157.

- Bouvry, M. and Rau, M.E. (1984). Paramphistomum spp. in dairy cattle in Quebec. Can. Vet. J., 25: 353-356. 
- Campbell, W.C. and Benz, G.W. (1984). Ivermectin. A review of efficacy and safety. J. Vet. Pharmacol. Therap. 7: 611-612.

- Dreyfuss, G.; Novobisky, A.; Vignoles, P.; Bellet, V.; Koudela, B. and Rondelaud, D. (2007). Prevalence and intensity of infection in the lymnaeid snail Omphiscola glabra experimentally infected with Fasciola hepatica, Fascioloides magna and Paramphistomum daupneyi of Helminthology. 81: 7-12.

- Drurag,R.and Wallington,E.(1980). Carlton's histological techniques. $4^{\text {th }}$ ed. Oxford University Press, New York.

- Dube, S.; Dlamini, N.R.; Masanganisek, K.E. and Dube, C. (2004). Abattoir studies on paramphistomes recovered from cattle in Masuingo and Monicaland province of Zimbabwe. Folia Veterinaria, 48(3): 123-129.

- Dutta, S.; Majumdar, P. and Basak, D.K. (1995). Studies on the incidence of paramphistomiasis in cattle (Bos indicus) in West Bengal. Indian Journal of Veterinary Medicine, 15(2): 84-86.

- El-Refaii,A.H.(1993).Entamoeba bovis liebetanz 1905 recorded from large ruminants in Egypt. J. Egypt. Soc. Parasitol, 23(1): 239-245.

- El-Seify, M.; El-Bahy, N.M.; Abdo-Rabo, T.M. and El-Shahawy, I.S. (1999). Some morphological studies on Paramphistomidea in Kafr El-Sheikh governorate. Alex. J. Vet. Sci., 15(5): 981-993.

- Ferre, I.; Shen, S.L.; Gu, Y.F.; Chen, L.; Xi, J.; Wang, B.Y.; Gonzalez Gallego, J. and Meo, X.Z. (1997). Prevalence of Fasciola hepatica and Paramphistomum spp. infection in water buffalo in Anhui and Jiangsu provinces (China). Proceedings $5^{\text {th }}$ World Buffalo Congress. Royal Palace, Caserta, Italy, 574-577. 
- Galdhar, C.N. and Roy, S. (2005). Studies on prevalence of bovine paramphistomiasis in Chattisgarh state India. Indian Veterinary Journal, 82(9): 938-940.

- Galdhar, C.N.; Roy, S.; Ali, S.L.; Maiti, S.K. and Awasthi, B.K. (2002). National symposium and annual convention of ISVM on recent trends in diagnostic and therapeutics of animal disease. Feb. 1416, Bikaner.

- Hafeez, M.; Ramesh, D.; Reddy, C.V.S.; Devi, D.A.; Chandra, M.S. and Sameena, S.K. (2006). Detection of Paramphistomum epiclitum infection in sheep by dot. Elisa, Indian Journal of Animal Sciences, 76(9): 962-963.

- Hanna, R.E.B.; Williamson, D.S.; Mattison, R.G. and Nizami, W.A. (1988). Seasonal reproduction in Paramphistomum epiclitum and Gastrothylax crumenifer, rumen paramphistomes of Indian water buffalo and comparison with billiary Paramphistome gigantocotyle explanatum. International Journal for Parasitology, 18: 513-521.

- Haridy,F.M.; El-Sherbiny,J.T.and Morsy,T.A.(2006). Some parasitic flukes infecting farm animals in Al-Santa center, Gharbia Governorate, Egypt. Journal of the Egyptian Society of Parasitology, 36 (1): 259264.

- Hirani, N.D.; Katariya, M.A.; Abdullah Patel, Hasnani, J.J.; Kathiria, L.G.; Patel, P.V. and Patel, A. (1999). Prevalence of gastrointestinal parasitic infections in cattle and buffaloes of Kheda district of Gujar. Journal of Veterinary Parasitology, 13: 147-149.

- Juyal, P.D.; Gupta, M.P.; Kaurk, K.B. and Hassan, S.S. (2003). Epidemiological status of paramphistomiasis in domestic ruminants. Punjab Veterinary Journal 2: 100-102. 
- Kelly, W.R. (1984). Veterinary clinical diagnosis. $3^{\text {rd }}$ ed. Baillieve Tindal.

- Khan, A. and Anjum, A.D. (1994). Liver paramphistomiasis in a buffalo in Pakistan. Buffalo Journal, 10(2): 185-188.

- Khan, U.J.; Akhtar, T.; Maqbool, A. and Anees, A. (2006). Epidemiology of Paramphistomiasis in buffaloes under different managemental condition at four district of Punjab province, Pakistan Iranian Journal of Veterinary Research, 7(3): 68-72.

- Kozakiewicz, B. (1980). The dynamic of occurrence of paramphistomiasis in cattle and sheep in Poznan area. Poland Medycyna Weterynaryjna, 36(3): 144-146.

- Kumari, P.S. and Hafeez, M.D. (2005). Prevalence of Paramphistomiasis in cattle in Chittor district of Andhra Pradesh. Indian Journal of Parasitic Disease, 29(1): 1-8.

- Luc, P. and Thang, T. (1999). Paramphistomatidae infestations of buffaloes in North Vietnam. Knoa Hocky Thuat Thuy, 6(1): 57-62.

- Mahapatra, P.K.; Misra, S.C.; Panda, M.R. and Rao, A.T. (1990). Indian Vet. J. 67: 756. Cited after Roy et al. (2004).

- Manna, A.K.; Pramanik, S. and Mukherjee, G.S. (1994). Incidence of Paramphistomiasis in west Bengal. Indian Journal of Animal Health, 33(2): 87-89.

- Martin, W.S. (1987). Veterinary epidemiology. 3rd ed. Iowa State University, Congress Library.

- Moghoddar, N. and Khanitapeh, N. (2003). Prevalence of Paramphistomes in sheep and goat in the Fars province of Iran. Iranian Journal of Veterinary Research, 4(2): 166-170. 
- Pal, A.R. and Qayyum, M. (1993). Distribution of gastrointestinal amphistomes and cestodes in small ruminants grazed on irrigated and non irrigated pasture-zones. Proceeding of Pakistan Congress of Zoology 13: 307-313.

- Prasad, K.D. and Bharti,P.(2001). Assessment of oxyclozanide efficacy against chronic natural fascioliasis or paramphistomiasis in cattle and buffaloes. Journal of Research Birsa Agricultural University, 13(2): 245-248.

- Rangel Rulz, L.J.;Albores Brahms,S.T.and Gamboa Aguilar,J. (2003). Seasonal trends of Paramphistomum cervi in Tabasco, Mexico. Veterinary Parasitology, 116(3): 217-222.

- Rapic, D. (1980). Action of Nilsan on paramphistomiasis in cattle. Praxis Veterinaria, 28(1/2): 15-18.

- Reddy, M.R. and Hafeez, M. (1986). Niclosamide an effective drug against amphistomasis of sheep. Cheiron, 15(1): 29-30.

- Rolfe, P.; Boray, J. and Collins, G. (1994). Pathology of infection with Paramphistomum ichikaway in sheep. International Journal Parasitology, 24(7): 995-1004.

- Rolfe, P.F. and Boray, J.C. (1987). Chemotherapy of Paramphistomiasis in cattle. Australian Veterinary Journal, 64(11): 328-332.

- Sey, O.; Prasitirat, P.; Romratanapun, S. and Mohkaew, K. (1997). Morphological studies and identification of rumen flukes of cattle in Thailand. Rivista Di Parasitologia, XIV(2): 247-256.

- Singh, R.P.; Saha, B.N.; and Jha, G.J. (1984). Histopathology of the duodenum and rumen of goats during experimental infections with paramphistomum cervi. Veterinary Parasitology, 15(1): 39-46. 
- Snedecor, G.W. and Cochran, W.G. (1980). Statistical methods. $8^{\text {th }}$ ed. The Iowa State University Press, USA.

- Sobih, M.A. and Hassan, M.G. (1992). Prevalence of gastrointestinal parasites among cattle and buffaloes in Ismailia governorate. Zag. Vet. J., 20(2): 299-310.

- Soulsby, E.J.L. (1982). Helminths, Arthropoda and Protozoa of domesticated animals. $7^{\text {th }}$ ed. Baillier, Tindal and Cassel, London.

- Stripalwit, P.; Wongsawad, C.; Wongsawad, P. and Anuntalabnochai, $\boldsymbol{P}$. (2007). High annealing temperature random amplified polymorphic DNA analysis of three paramphistome flukes from Thiland. Experimental Parasitology, 115(1): 98-102.

- Vartic, N.; Zagreanu, C.; Trica, Z. and Suteu, E. (1982). Epizootiological, pathological, clinical, therapeutic studies of paramphistomiasis in cattle and sheep. Seminarul Amerliorarea Technologia Si Pathologia Rumenga-toarelor, Volumul, VII: 29-30.

- Wang, C.R.; Qiu, J.H.; Zhu, X.Q.; Han, X.H.; Ni, H.B.; Zhoo, J.P.; Zhou, Q.M.; Zhang, H.W. and Lun, Z.R. (2006). Survey of Helminths in adult sheep in Heilongjiang Province, People's Republic of China. Veterinary Parasitology, 140: 378-382.

- Yamaguti,S.(1958). Systema helminthium,vol.2, the digenetic trematodes of vertebrates past II. Interscience Publishers Inc., New York.

- Zinsstag,J.;Ankers, P.H.;Dempfie,L.; Njie,M.; Kaufmann, J.; Itty, P.; Pfister, K. and Pandey, V.S. (1997). Effect of strategic gastrointestinal nematode control on growth of N'Dama cattle in Gambia. Veterinary Parasitology, 68: 143-153. 


\section{دراسات على الإصابة بلديلان البارمفيستومه في المجترات}

مجلى حسانين الجعبرى - سلامه أحمد عثمان - أمبيره جعفر محود الطنويى قسم طب الحيوان - كلية لطب البيطري / جامعة كفر الثيخ

تم إجر اء هذه الدراسة للتعرف على بعض الجوانب الوبائية والإكلينيكية المختلفة للإصابة بديدان الكرش في المجترات خلال الفترة من يناير 2008 إلى ديسمبر 2008 بالإضافة إلى التعرف لهاه على كفاءة بعض الأدوية المستخدمة في العلاج. بفحص عدد 944 حيوان (314 أبقار، 218 جاموس، 410 أغنام) تم التأكد بالفحص المجهرى من إصابة 260 حيو ان بنسبة إصابة بلغت 27.43 \% كانت نسبة الإصابة 38.92\% ، 41.74 ، 10.98 في الأبقار و الجاموس والأغنام على التو الي

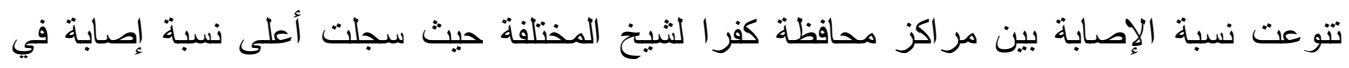
مركز الرياض وبيلا ولم تسجل اى إصابة في مركز بلطيم. بالفحص المجهرى نم التأكد من إصابة

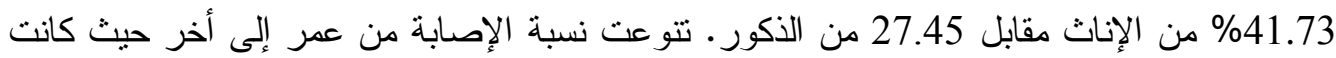

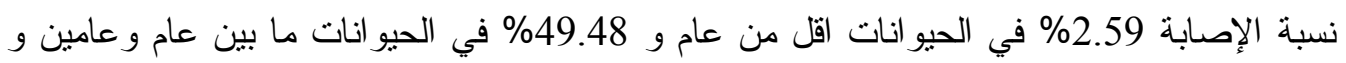

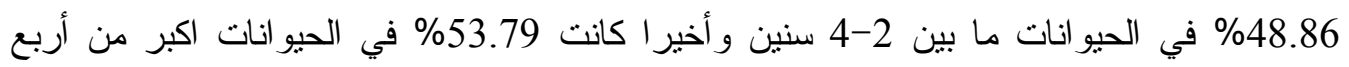
أعو ام. تباينت نسبة الإصابة من فصل إلى اخر حيث سجلت اعلى نسبة إصابة في فصل الربيع (43) \% تلاها فصل الخريف (32.25\%) ثم فصل الثناء (31\%) وسجلت اقل نسبة إصابة في فصل الصيف (3.32\%). بالفحص المجهرى أمكن التعرف على ثلاث أنواع من طفيليات ديدان الكرش Paramphistomum cervi, Cotylophoron cotylophorum Carmyerius gregarious الفحص الإكلينيكي تباينت الأعراض الإكلينيكية إذ إنعدمت فى الحيو انات ذات الإصابة الخفيفة

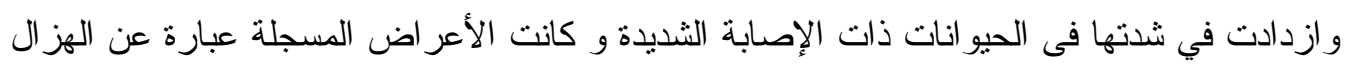

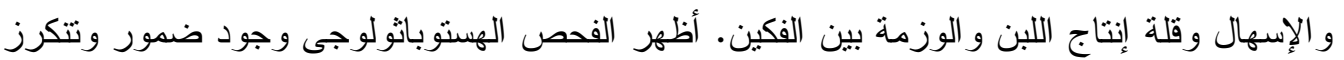

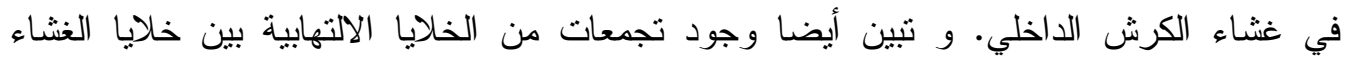

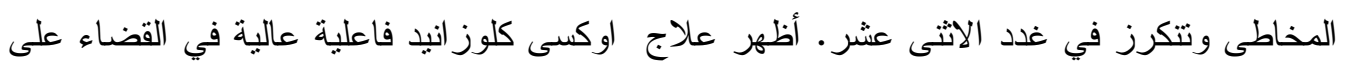
الطفيل حيث اعطى نسبة شفاء بمعدل 97.9\% مقارنة بعقار نيكلوز اميد الذي فثل في القضاء التام على الطفيل. 